\title{
Pathology Ink
}

National Cancer Institute

\section{Source}

National Cancer Institute. Pathology Ink. NCI Thesaurus. Code C126375.

Medical grade dye or pigment that is applied to surgically removed tissue specimens to maintain orientation and indicate tumor resection margins. 